\title{
Identifying the Relevant Factors in Newspaper Advertising Effectiveness
}

\section{Cristóbal Benavides ${ }^{1}$ Ricardo Leiva²}

Recibido: 2014-03-15

Enviado a pares: 2014-03-15

DOI: 10.5294/pacla.2014.17.4.6
Aprobado por pares: 2014-06-19

Aceptado: 2014-07-26

\section{Para citar este artículo / To reference this article / Para citar este artigo}

Benavides, C. y Leiva, R. Diciembre de 2014. Identifying the Relevant Factors in Newspaper Advertising Effectiveness. Palabra Clave 17(4), 1114-1134. D0I: 10.5294/pacla.2014.17.4.6

\section{Abstract}

This study explores several factors in order to establish which are the most important in driving local newspaper readers to buy, visit shops and look for additional information about products or services promoted by ads. The behavior in the process of buying is a consequence of a complex interplay among cultural, social, personal and psychological dimensions. This process -which occurs prior to the action- has relevant implications and marketing departments should pay attention to it. A series of hypotheses based on how advertising appeals to consumers and how it affects decision making at the time of buying are tested using a survey administered to a sample of 1,333 respondents in Chile. A discriminant analysis is also performed to find out why some newspapers readers are driven to buy goods or services, visit a shop or search for more information. The results show that the appeal of the deal advertised is the single most important factor in explaining subsequent consumer behavior.

\footnotetext{
1 Universidad de los Andes, Santiago de Chile, cbenavides@uandes.cl

2 Universidad de los Andes, Santiago de Chile, rleiva@uandes.cl
} 


\section{Keywords}

Advertising, newspaper, effectiveness, media marketing. (Source: Unesco Thesaurus).

\section{La identificación de los factores relevantes en la efectividad de la publicidad en prensa}

\section{Resumen}

Este estudio explora varios factores con el fin de establecer cuáles son los más importantes en motivar a los lectores de periódicos locales a comprar, visitar tiendas y buscar información adicional acerca de los productos o servicios promovidos en los anuncios. El comportamiento durante el proceso de compra es consecuencia de una compleja interacción de dimensiones culturales, sociales, personales y psicológicas. Este proceso -el cual se produce antes de la acción- tiene implicaciones relevantes y los departamentos de mercadeo deben prestar atención a ello. Una serie de hipótesis basadas en la forma como la publicidad atrae a los consumidores y en cómo afecta la toma de decisiones al momento de la compra fueron puestas a prueba usando una encuesta que fue administrada a una muestra de 1.333 personas encuestadas en Chile. También se realizó un análisis discriminante para averiguar por qué algunos lectores de periódicos se ven motivados a comprar bienes o servicios, visitar una tienda o buscar más información. Los resultados muestran que el atractivo de la oferta anunciada es el factor más importante para explicar el comportamiento posterior del consumidor.

\section{Palabras clave}

Publicidad, periódico, efectividad, mercadeo en medios de comunicación. (Fuente: Tesauro de la Unesco). 


\section{A identificação dos fatores relevantes na efetividade da publicidade em imprensa}

\section{Resumo}

Este estudo explora vários fatores com o objetivo de estabelecer quais são os mais importantes em motivar os leitores de jornais locais a comprarem, visitarem lojas e buscarem informação adicional sobre os produtos ou serviços promovidos nos anúncios. $\mathrm{O}$ comportamento durante o processo de compra é consequência de uma complexa interação de dimensões culturais, sociais, pessoais e psicológicas. Esse processo —o qual se produz antes da ação — tem implicações relevantes e os departamentos de marketing devem prestar atenção a isso. Uma série de hipóteses baseadas na forma como a publicidade atrai os consumidores e em como afeta a tomada de decisões no momento da compra foi provada usando um questionário que foi administrado a uma amostra de 1.333 pessoas no Chile. Uma análise discriminadora também se realizou para averiguar por que alguns leitores de jornais são motivados a comprarem bens ou serviços, visitarem uma loja ou buscarem mais informação. Os resultados mostram que o atrativo da oferta anunciada é o fator mais importante para explicar o comportamento posterior do consumidor.

\section{Palavras-chave}

Publicidade, jornal, efetividade, marketing em meios de comunicação. (Fonte: Tesauro da Unesco). 


\section{Theory}

\section{The Advertising Environment}

What is advertising supposed to do? A classic approach in the area of marketing has defined three major functions of advertising: (1) awareness and knowledge, related to information or ideas; (2) liking and preference, related to favorable attitudes or feelings towards something; and (3) conviction and purchase, related to actions (Lavidge \& Steiner, 1961, p. 60). These three advertising functions are related respectively to the traditional psychological division of behavior into three dimensions: (1) the cognitive, intellectual or rational one; (2) the emotional or affective component; and (3) the motivational or striving state, associated with the tendency to treat objects as positive or negative goals (p. 60). Though the primary goal of advertising is to produce sales, only one of the three major functions described is directly related to the immediate action of selling. The other two functions - knowledge and preference — could be useful to producing sales in the long-term, because "ultimate consumers normally do not switch from disinterested individuals to convinced purchasers in one instantaneous step" (p. 59). Rather, the purchase is only the final stage of a process in which consumers go through a series of steps. Consequently, advertising can be oriented to letting uninformed people know about the launch of a new product/service or about what that product/service offers; it can be designed to create favorable attitudes or feelings towards a product/service and ultimately produce a preference; or it can be conceived to convince informed people with favorable attitudes and feelings toward the product/ service to buy it (p. 59).

This traditional, one-way linear approach to advertising has been challenged of late. The traditional approach to advertising was based on the assumption that the marketer sends out messages, hopes they are received, and the consumer is a passive host "in a sanitary world where only the marketer's message is seen or heard” (Schultz, Tannenbaum \& Lauterborn, 1992, p. 110). In effect, the traditional model ignored the impact of competitive messages and forms of communication. "The greatest challenge to the model is that it is hypothetical and, despite its acceptance, the- 
re is practically no scientific evidence that it correctly assesses the way the human responds to advertising or marketing communication" (Schultz \& Schultz, 2004, pp. 86-87).

The traditional approach to advertising was developed by researchers who had little way of measuring the actual impact of their communications, at a time when "markets were so diffused, channels so complex, and technology and measurement instruments so crude that only broad approximations of behavior, generally in a very aggregated form, were possible" (Schultz, et al., 1992, p. 110).

\section{Advertising Effectiveness}

In every stage, advertising effectiveness - the attention paid and the response to ads by people exposed to them — can be affected by four groups of factors: a) the characteristics of the ad; b) the characteristics of the receiver; c) the situation-context-environment; and d) the peculiarities of the source-medium-channel (De Pelsmacker, Geuens, \& Anckaert, 2002).

Besides the characteristics of the specific ad and the receiver, the situation or environment during the exposure to the ad may influence the receiver's response to it. If a person is not able to pay enough attention to an ad because he is tired or sick, he cannot be rightly exposed to it: "For example, when somebody starts to talk to a person who is watching a television commercial, it will prevent him or her from fully understanding the message" (De Pelsmacker et al., 2002).

The peculiarities and nature of the source-medium-context of the message also influence the response to the message and the attention it receives (Juntunen, 1995; Schumann \& Thorson, 1990). These peculiarities are not only present at the time of discriminating between different kinds of media, but also when varying the aggregation or presentation of ads in one medium. In effect, the language, appeal, and narrative of ads in print or on broadcasted outlets are clearly different, but varying the aggregation and/or presentation of ads in the same kind of media also can result in very different responses from the receivers. Specifically, a different number, se- 
quence, or placement of ads in one medium might produce a very contrasting response from exposed individuals (Aaker, Stayman, \& Hagerty, 1986; Finn, 1988; Ha, 1996; Olsen, 1994; Pieters, \& De Klerk-Warmerdam, 1993). This influence of the source in advertising effectiveness has been labeled as media context (De Pelsmacker et al., 2002, p. 59).

The context of the ad - what is around an individual ad inside a medium - may be more appropriate for certain types of advertising than for others (Derks \& Arora, 1993; Perry et al., 1997). It is not the same to display an ad combined with others into clusters in a newspaper or in commercial blocks on television or radio, than to present the same ad inserted into a news article with a congruent context-e. g. an ad for suitcases next to a feature about traveling (Maclnnis \& Jaworski, 1989; Petty \& Cacioppo, 1986).

The congruence or contrast of the ad with its medium context-the close environment of the ad-might alter advertising effectiveness. In this sense, congruence between the message and its channel appears as a more convenient approach than contrast, generating higher recall and better attitudes toward the ad (De Pelsmacker et al., 2002). For instance, people reading a sports magazine with a relaxed tone may be more willing to pay attention and recall a humorous ad offering sports complements. It is believed that processing a message with a style similar to that of the media context is easier, because both share common knowledge structures (De Pelsmacker et al., 2002). "Ads that show elements that are relevant to or congruent with the mood of a subject at that particular moment may be accessed and processed more easily" (p. 50).

\section{Newspapers as Advertising Vehicles}

Newspapers have been advertising media for centuries. Indeed, newspapers and magazines were the only major media available to advertisers for a long time (Belch \& Belch, 2012). Ninety years after the invention of the printing press by Gutenberg — in around 1438 - the first published ad appeared in a German news flyer, announcing the miraculous benefits of a mysterious drug (Russell, Lane \& Kleppner, 1993). However, newspapers 
are no longer the primary advertising vehicle in the United States. According to recent reports, US newspapers are the fourth advertising channel, with a share of $10.2 \%$, after direct mail (26.2\%), television (26.1\%), and the digital/online format (14.3\%) (Cross \& McLeod, 2012). Spain follows a slightly different path. Newspapers - with an $8.5 \%$ share- are behind direct mail and telemarketing (25\%) and television (18.5), but still ahead of the digital/online format (7.5\%) (VV.AA., 2013).

Advertising was once the major source of revenue for newspapers. On average, between $70 \%$ and $80 \%$ of total newspaper revenue used to come from ads; the rest came from the sale of copies at newsstands and subscriptions (Belch \& Belch, 2012; Mings \& White, 2000). Thanks to this mix, the press was one of the most successful businesses in the second half of the last century. Publishers in the US enjoyed steady profit margins of more than $12 \%$ per year for decades. These margins outscored those of other very successful industrial sectors, such as pharmaceuticals (9\%), chemicals (8\%), and metallurgical products (7\%) (Picard, 2000).

Newspaper reading habits have changed, declining steadily since irruption of the broadcast media, as consumers began to prefer radio and particularly television as their primary source, not only for entertainment but also for information (Belch \& Belch, 2012). Later, the emergence of the Internet accelerated the decline of the newspaper industry, which reached its full maturity at the end of the last century. In recent years, the Internet has become the first source of news, surpassing the print media (Pew Research Center for the People \& the Press, 2008).

Today, readers do not seem to be willing to pay for print newspapers, because they can get online sports, business, national and international news commoditized and do not perceive enough of a difference to pay for something they can get for free (Belch \& Belch, 2012). The willingness to pay for news is lower in the case of the online format. Different surveys show most people are not inclined to pay for online news and would abandon those newspapers or outlets that charge for articles or features (Chyi, 2005; EuropeMedia, 2002; NewMediaAge, 2009; PriceWaterhouseCoopers, 2009). 
As the Internet is now the first source of news for consumers, it has attracted more and more advertisers. This explains why an Internet company such as Google, founded 14 years ago, now makes more money from advertising than the entire newspaper industry, which has been around for more than one hundred years. In the first six months of 2012, Google's advertising revenues reached $\$ 20.8$ billion, while the entire US print medianewspapers and magazines_-generated $\$ 19.2$ billion on print advertising (Richter, 2012).

Though the online offering of Google and other aggregators separately does not replace the quality and informative extension of newspapers, it does replace some of the individual components newspapers offer by providing a place for commentary, supplying entertainment, forming communities and reporting on specific issues. Each of these emerging competitors lacks something that is fundamental to most newspaper companies, but, taken together, they have been successful in competing with newspapers and destroying the informative monopoly they once enjoyed (Anthony \& Gilbert, 2006).

\section{The Decline of Newspapers as Advertising Channels}

The change in the technology cycle suffered by the newspaper industry was exacerbated by the last economic crisis, with severe consequences for advertising expenditure. Classified ads, for instance, which used to represent a third or a fourth total newspaper revenue, have abandoned print outlets and now can be found at online sites such as Craiglist.com, because these offer a more dynamic, flexible, rapid, and personalized presentation of products and services (Evans \& Wurster, 1997).

The money provided to newspapers by classified ads almost evaporated in 12 years: it was 19.6 bn US dollars in 2000 - the peak in the history of American newspapers - and dropped to 5bn in 2011 (-74\%) (Newspaper Association of America, 2013). Total advertising income for American newspapers followed a similar trend between those years, having fallen from 48.6bn in 2000 to 20.6bn in 2011 (-59\%) (Newspaper Association of America, 2013). A similar decline can be observed in European countries 
such as Spain. Advertising expenditure in Spanish newspapers reached 1.8bn euros in 2007, and dropped to 766 million euros in 2012 (VV. AA., 2013).

Online advertising has yet to emerge as a profitable alternative to compensate for the losses coming from the decline in print advertising. Though online advertising expenditure for newspapers has increased steadily in recent years - from 1.2 billion in 2003 to 3.2 billion in 2011 — it can hardly offset the dramatic losses experienced by the industry (Newspaper Association of America, 2013).

Many authors blame the press itself for this advertising scarcity. The newspaper industry was late to jump on the bandwagon of digital offerings and, when it did, it kept its old print business model. Its managers did not hesitate "to stall or delay any investment in technology that might cannibalize the core newspaper business" (Gilbert, 2005, p. 746). Some executives preferred to wait and see, and did not promote any online project until its adoption became inevitable. For years, newspapers delayed the moment of adopting business models and innovations that could lead them to develop online products at a profitable level (Gilbert, 2005).

In the nineties, newspapers missed the opportunity to reach advertisers who were trying to target individuals with personalized messages. In contrast, most of the new players in the field of online media, such as Yahoo!, Monster.com and Cnet, developed business models that took advantage of interactive opportunities and sold their services to advertisers who had not invested in the traditional newspaper advertising market, because they wanted to run direct-to-consumer campaigns (Gilbert, 2003). "Print newspapers continued to sell advertising through their established sales channels to established customers who were not demanding the new direct-advertising products" (p. 31). Newspapers failed to sell ads to e-mail advertisers, to those that target specific demographic groups, and to those who engage in usage targeting; i.e. aiming at someone who usually reads the sports page, for example. "As a result, they were missing $40 \%$ of their potential sales opportunity as compared with the typical online entrant” (p. 31). 


\section{The Newspaper Advertising Offer}

In spite of the huge challenges and the turbulence facing newspapers in industrialized countries, they still remain a primary means of advertising, because they provide unique advantages to both advertisers and readers (Russel \& Lane, 2001). Newspapers have many competitive advantages to offer advertisers: a) advertising exposure in newspapers is very effective, especially among people over 35 years of age; $b$ ) advertising in newspapers is very flexible and provides a broad range of colors, sizes, prices, and designs — displays, coupons, inserts, etc.; and c) newspapers are a credible, convenient, and opportune source of information (Russell et al., 1993; Russel and Lane, 2001). Several studies have also shown that newspapers remain highly popular media among customers, because they: a) help consumers to decide where to shop; b) are used more extensively when people are willing to make a purchase; c) are most effective in achieving the objectives of advertising; and d) are very credible media (Radio Advertising Bureau, 1997).

Newspapers also have some disadvantages as advertising channels: a) they are sometimes overloaded with ads - surpassing $60 \%$ of the available space; considering the average reader spends around 30 minutes per day reading them, it is possible to assume that many ads are commonly ignored by readers; $b$ ) newspaper circulation and its penetration have fallen steadily in recent years, especially among younger people: c) advertising costs have soared in recent years, decoupling from the decrease in circulation and penetration that follows a divergent trend; and d) newspapers face growing competition from broadcast media and the digital/online format (Russell et al., 1993).

\section{Advertising and the Purchase Decision}

The role played by newspapers and other media in the promotion of commercial products was studied extensively for many years As of the first empirical marketing studies, the media's role in the promotion and advertising of commercial goods was directly associated with a higher level of consumer engagement with products. Reierson (1967) found, at the end of the sixties, that exposure to print ads and media content could provoke an immediate 
response from receivers, changing the consumers' perception toward the evaluated product. The same author found a direct relationship between the amount of information received by some people about a specific category of products and the change in their perception about that category of products, compared to people who were not exposed to information and did not change their perception as a result (Reierson, 1967).

Consumers are constantly faced with the need to make decisions about products and services. Some decisions are very important and entail great effort, but others are practically automatic and people make them out of habit. Evaluating and buying products are very complex processesoften analyzed separately — and depend on many variables (Bilkey \& Nes, 1982; Kotler \& Gertner, 2002; Peterson \& Jolibert, 1995).

The decision-making process is further complicated by the huge number of decisions made by people every day in a marketplace environment characterized by consumer hyper-choice (Solomon, 2007). This hyper-choiceness has been exacerbated by irruption of the Internet. For instance, the Web has changed the way many consumers search for information about products and services. If consumers in the past experienced a deficit of information about products and services, they now experience just the opposite: an oversupply of data, details, facts and statistics that can be more confusing than enlightening (Solomon, 2007). Compared to the Internet, newspapers seem to offer a key competitive advantage to advertisers: they filter, condense, classify, and present data in an orderly fashion (Solomon, 2007). However, the media are not the only relevant factor when it comes to studying consumer behavior. Consumers usually pay attention to a wide range of extrinsic factors when choosing a product, such as price, brand image, packaging, country of origin, and post-selling service, and consider some intrinsic elements, such as design, style, color, etc. (Kotler and Gertner, 2002). Each of these factors can play a significant role. For instance, consumers may tend to prefer local products to foreign ones, ceteris paribus, unless imported goods are undoubtedly more convenient than local ones in terms of price and quality (Elliott \& Cameron, 1994). Besides, consumers seem to have a "hierarchy of countries" when it comes to pre- 
ference for imported goods. Products from the United States are at the top of this hierarchy, followed, in descending order, by those from Germany, Japan, Northern Europe, Southern Europe, the rest of the Asia-Pacific region, South America and Africa (Liefeld, 1993).

When consumers evaluate and select products in the marketplace, several cognitive and emotional processes take place in their minds. This happens because consumers establish a relationship with products based on feelings, attitudes, and intentions (Liefeld, 1993). People respond to the feelings, attitudes, and intentions generated by products, with perceptions (evaluation) and/or actual action (selection). In the first case, people form images in their minds, and do not necessarily make a decision. In the second case, perception leads to concrete and observable actions, with purchase or rejection of the product being the most common ones (Liefeld, 1993).

Buying a product requires a higher level of engagement by the consumer than merely evaluating a product. Buying tends to be considered a response to a problem, following a series of steps in order to arrive at a solution. This process is commonly composed of four stages: a) problem recognition; (b) information research; c) evaluation of alternatives; and d) product choice (Solomon, 2007).

Once a consumer recognizes a purchasing-decision problem, he needs adequate information to solve it. The subsequent search for information can be internal or external. Indeed, when a person is faced with a purchasing decision, he usually recalls and compares the evaluated product or service to many others already stored in his mind. In doing so, he engages in an internal search, scanning his own memory to assemble information about different product alternatives. But this may be not enough for those market-savvy consumers who need to supplement their internal search information with an external search, based on advertisements, friends' recommendations, word-of-mouth, etc. (Solomon, 2007).

In any case, people do not always follow a logical sequence when buying. Sometimes, impulses might be more powerful than rationale. Solo- 
mon (2007) believes a helpful way to characterize the decision-making process is to consider how intense the effort has been to reach a decision:

a. An extended problem-solving process at the time of purchase is closely related to the traditional decision-making perspective. It is initiated by a motive that is fairly important to the person, who feels the eventual decision carries a fair degree of risk. The consumer collects as much information as possible and evaluates each product alternative. The evaluation is often based on a consideration of brand attributes and how those attributes fit into a set of desired characteristics.

b. A limited problem-solving process means the buyer is not overly motivated to search for information or to evaluate each product alternative rigorously. Instead, he uses simple decision-making rules to choose among the alternatives.

Consumer purchase decisions can also be categorized according to consumer utility. Regarding this categorization, Peter and Tarpey (1975) differentiated among three consumer decision strategies: a) minimization of expected negative utility (perceived risk); b) maximization of expected positive utility (perceived return); c) and maximization of expected net utility (net perceived return). Both authors concluded the net perceived return model could explain more variance in brand preference than the other two models (Peter \& Tarpey, 1975).

Consumers consider sets of product attributes by using different rules, depending on the complexity of the decision and its importance to them. One classification presented by Solomon (2007) divides decision-making between compensatory and non-compensatory categories:

a. Compensatory: This is when people give a product a chance. Consumers who employ these rules tend to be more involved in the purchase and, thus, are willing to consider the entire picture in a more exacting way. The selection is carried out after analyzing positive and negative attributes. However, people sometimes also take into account the im- 
portance of positive attributes, essentially multiplying brand ratings by importance weights (Alba \& Marmorstein, 1987).

b. Non-compensatory: People eliminate all the options that do not meet certain basic standards. This type of decision is made by consumers who only buy well-known brands names and would not consider new options, even if they were equal or superior to existing ones. When people are less familiarized or not motivated to process information, they tend to use simple non-compensatory rules (Park, 1976).

\section{The Appeal of Advertising}

What attributes should advertising comply with to be effective and appealing? Some marketers and authors have listed a series of attributes to answer that question. An effective and appealing advertisement should be based on the following elements: a) a powerful strategy, which is considered the core of advertising; $b$ ) an engaging idea and a promise of a benefit or deliverable to the consumer; and c) a message that stands out and is remembered (Russell et al., 1993; Russel and Lane, 2001).

Based on these attributes, we propose the following hypotheses:

$\mathrm{H1}$ : An effective and appealing offer advertised in a local newspaper is positively related to motivate the consumer to buy the product offered.

$\mathrm{H} 2$ : An effective and appealing offer advertised in a local newspaper is positively related to motivate the consumer to visit shops where the product being offered is sold.

H3: An effective and appealing offer advertised in a local newspaper is positively related to motivate the consumer to look for additional information about the product or service being promoted in the ad.

\section{Method}

This study explores several factors to determine which are the most important in producing an active response from local newspaper readers who are exposed to print ads. These active responses to advertising exposure were 
classified as: a) buying; b) visiting shops; and c) looking for additional information about the product or service being promoted.

A quantitative face-to-face survey of 1,333 persons was carried out to know how people respond to an ad considered to be "appealing". The survey was conducted in ten Chilean cities (Antofagasta, La Serena, Valparaíso, Viña del Mar, Rancagua, Curicó, Talca, Chillán, Concepción and Puerto Montt) between June and July, 2012. Those surveyed were between 15 and 65 years of age; $48.6 \%$ were men and $51.4 \%$ women. This is in line with the gender distribution of the Chilean population, according to the 2002 Census. More than half of those surveyed (54\%) had read a newspaper during the previous week and almost a third $(28 \%)$ acknowledged having read one every day. The margin of error was $+/-3.7 \%$, with a $95 \%$ confidence interval. The sample was stratified and then adjusted by age and income, according to available official statistics.

Those surveyed were asked if advertising in local newspapers in Chile: $a$ ) is appealing or attractive, b) offers good deals; and c) is helpful in making a buying decision. These variables were related to reading habits and perceptions about the local press declared by the respondents: a) reading frequency; $b$ ) level of satisfaction with information provided by local newspapers; c) level of satisfaction with entertainment provided by local newspapers; d) level of trustworthiness; e) level of quality; and f) influence of local newspapers. All these variables were measured using Likert scales that ranked levels of agreement/disagreement and satisfaction/dissatisfaction stated by the people surveyed, where 1 is equal to total disagreement or dissatisfaction and 5 is equal to total agreement or satisfaction.

A discriminant analysis also was performed to find out why some newspaper readers exposed to ads are motivated to: a) buy; b) visit a shop; or c) acquire more information.

\section{Results}

Table 1 shows the means, standard deviations, and correlations among the variables used in the analysis. The highest correlations occur between re- 
ading frequency and completeness of information and entertainment needs. This result is not surprising, since those who read the newspaper more frequently tend to value it more than those who do not do so. For the same reason, quality of the newspaper is moderately correlated with completeness (information and entertainment) and trust. However, influence of the newspaper shows low correlations with all other variables. This might be because local newspapers serve only an informative role and do not influence public issues.

\section{Table 1. Means, Standard Deviations and Correlations}

\begin{tabular}{|l|l|l|c|c|c|c|c|c|c|c|c|}
\hline \multicolumn{2}{|l|}{} & Median & S.D. & 1 & 2 & 3 & 4 & 5 & 6 & 7 & 8 \\
\hline 1. & Ad attractiveness & 2.86 & 1.353 & 1.00 & & & & & & & \\
\hline 2. & $\begin{array}{l}\text { Offers in the } \\
\text { newspaper }\end{array}$ & 3.05 & 1.352 & $0.592^{* *}$ & 1.00 & & & & & & \\
\hline 3. & $\begin{array}{l}\text { Help in buying } \\
\text { decision }\end{array}$ & 3.05 & 1.194 & $0.531^{* *}$ & $0.439^{* *}$ & 1.00 & & & & & \\
\hline 4. & $\begin{array}{l}\text { Reading } \\
\text { frequency }\end{array}$ & 3.68 & 1.980 & $0.319^{* *}$ & $0.313^{* *}$ & $0.289^{* *}$ & 1.00 & & & & \\
\hline 5. & $\begin{array}{l}\text { Cover } \\
\text { information } \\
\text { needs }\end{array}$ & 3.30 & 1.818 & $0.361^{* *}$ & $0.379^{* *}$ & $0.306^{* *}$ & $0.745^{* *}$ & 1.00 & & & \\
\hline 6. & $\begin{array}{l}\text { Cover } \\
\text { entertainment } \\
\text { needs }\end{array}$ & 3.69 & 1.592 & $0.350^{* *}$ & $0.357^{* *}$ & $0.289^{* *}$ & $0.679^{* *}$ & $0.820^{* *}$ & 1.00 & & \\
\hline 7. & Trustworthiness & 2.75 & 1.171 & $0.368^{* *}$ & $0.400^{* *}$ & $0.281^{* *}$ & $0.491^{* *}$ & $0.545^{* *}$ & $0.487^{* *}$ & 1.00 & \\
\hline 8. & Quality & 2.43 & 1.426 & $0.399^{* *}$ & $0.458^{* *}$ & $0.319^{* *}$ & $0.488^{* *}$ & $0.569^{* *}$ & $0.557^{* *}$ & $0.676^{* *}$ & 1.00 \\
\hline 9. & Influence & 3.15 & 1.758 & 0.029 & $0.310^{* *}$ & $-0.077^{*}$ & $0.218^{* *}$ & $0.241^{* *}$ & 0.268 & $0.296^{* *}$ & $0.330^{*}$ \\
\hline & $\mathrm{N}=838 ;{ }^{*} \mathrm{p}<0.05 ;{ }^{* *} \mathrm{p}<0.01$ & & & & & \\
\hline
\end{tabular}

A discriminant analysis was performed using four categories associated with consumer behavior after being exposed to advertising in the local newspaper; namely, buying, seeking more information, visiting the shop and not taking any specific action. The analysis produced two significant functions defined by eight significant variables (Table 2 ).

The first function is defined by help in the buying decision, ad attractiveness, and covering information needs. The second function is defined by influence, offers in newspapers, quality, trustworthiness, and covering entertainment needs. A look at the group centroids (Table 3) shows the first discriminant 


\section{Table 2. Results of the Discriminant Analysis}

\begin{tabular}{|c|c|c|c|c|}
\hline \multirow[b]{2}{*}{ Variables } & \multicolumn{2}{|c|}{ Function 1} & \multicolumn{2}{|c|}{ Function 2} \\
\hline & $\begin{array}{l}\text { Standardized Canonical } \\
\text { Discriminant Coefficients }\end{array}$ & $\begin{array}{c}\text { Correlations with } \\
\text { Discriminant Score }\end{array}$ & $\begin{array}{l}\text { Standardized Canonical } \\
\text { Discriminant Coefficients }\end{array}$ & $\begin{array}{l}\text { Correlations with } \\
\text { Discriminant Score }\end{array}$ \\
\hline $\begin{array}{l}\text { Help in the buying } \\
\text { decision }\end{array}$ & 0.53 & $0.76^{*}$ & 0.24 & 0.37 \\
\hline Ad attractiveness & 0.52 & $0.73^{*}$ & -0.42 & 0.18 \\
\hline Cover information needs & 0.31 & $0.42^{*}$ & -0.18 & 0.40 \\
\hline Influence & -0.43 & -0.28 & 0.48 & $0.77^{*}$ \\
\hline Offers in newspapers & -0.23 & 0.30 & 0.50 & $0.69^{*}$ \\
\hline Quality & 0.10 & 0.32 & 0.33 & $0.69^{*}$ \\
\hline Trustworthiness & -0.2 & 0.27 & 0.12 & $0.56^{*}$ \\
\hline $\begin{array}{c}\text { Cover entertainment } \\
\text { needs }\end{array}$ & 0.05 & 0.37 & 0.11 & $0.44^{*}$ \\
\hline Reading frequency & -0.01 & 0.34 & 0.02 & 0.36 \\
\hline Eigen value & \multicolumn{2}{|c|}{0.59} & \multicolumn{2}{|c|}{0.06} \\
\hline Canonical Correlation & \multicolumn{2}{|c|}{0.61} & \multicolumn{2}{|c|}{0.23} \\
\hline Wilk's Lambda & \multicolumn{2}{|c|}{0.59} & \multicolumn{2}{|c|}{0.94} \\
\hline$x^{2}$ & \multicolumn{2}{|c|}{422.74} & \multicolumn{2}{|c|}{46.61} \\
\hline $\mathrm{P}$ & \multicolumn{2}{|c|}{$<0.001$} & \multicolumn{2}{|c|}{$<0.001$} \\
\hline
\end{tabular}

\section{Table 3. Group Centroids for the Two Significant Discriminant Functions}

\begin{tabular}{|l|c|c|}
\hline \multicolumn{1}{|c|}{ Group Centroids } & Function 1 & Function 2 \\
\hline Buy & -1.69 & 0.66 \\
\hline Seek more information & -0.74 & -0.15 \\
\hline Go to the shop & -0.30 & -0.26 \\
\hline No action taken & 0.73 & 0.10 \\
\hline
\end{tabular}

function separates the no action taken group from the remaining groups. Similarly, the second discriminant function separates the buy group from the remaining groups. The buy group is characterized mainly as being seduced by appealing offers, because the local newspaper influences readers and is a source of quality information.

Finally, as shown in Table 4, the percentage of consumers correctly classified with the discriminant procedure was $52.1 \%$. This level compares favorably to the percentage that would be achieved by chance. 


\section{Table 4. Classification Results ${ }^{a}$}

\begin{tabular}{|l|c|c|c|c|}
\hline & \multicolumn{4}{|c|}{ Predicted Group Membership } \\
\hline Actual Group & 1 & 2 & 3 & 4 \\
\hline 1. Buy & $49.1 \%$ & $31.6 \%$ & $7.0 \%$ & $12.3 \%$ \\
\hline 2. Seek more information & 15.0 & 21.4 & 30.1 & 33.5 \\
\hline 3. Go to the shop & 8.7 & 18.5 & 22.1 & 50.8 \\
\hline 4. No action taken & 0.0 & 5.1 & 13.8 & 81.1 \\
\hline a Group cases correctly classified equal 52.1\%
\end{tabular}

\section{Final Remarks}

Based on a survey of 1,333 persons conducted in ten Chilean cities between June and July, 2012, it was possible to associate the satisfaction levels of those newspapers readers who said they pay attention to print news content and print advertising with several active purchase decisions taken by them.

A discriminant analysis performed with the data collected allows for the conclusion that people who were inspired to buy after reading local newspapers and paying attention to print ads were motivated mainly by the level of appeal and attractiveness of the deal offered in the ad, the level of influence exerted by the newspaper where the ad is run, and the level of the quality of information provided by the news outlet. What is not clear is the relationship between those variables and the actions of visiting a shop or looking for additional information about the product or service offered in the ad. Therefore, this article provides robust evidence of the strong relationship between the editorial role of a newspaper company - i.e. its mission as a provider of high quality information - and its commercial role —i. e. being an effective channel for advertisers who want to sell products.

\section{References}

Alba, J. \& Marmorstein, H. (1987). The effects of frequency knowledge on consumer decision making. Journal of Consumer Research, 14, 14-25. 
Associated Press Managing Editors (2009). Newsroom leader survey. Retrieved May 12, 2013 from: http://www.apme.com/soundingboard/newsroom/051209newsroom_survey.shtml

Belch, G. \& Belch, M. (2012). Advertising and promotion: An integrated marketing communications perspective. NY: McGraw-Hill/Irwin.

Bilkey, W. J. \& Nes, E. (1982). Country-of-origin effects on product evaluations. Journal of International Business Studies, 89-99.

Chyi, H. I. (2005). Willingness to pay for online news: An empirical study on the viability of the subscription model. Journal of Media Economics, 18(2), 131-142.

Cross, L., \& McLeod, N. (2012). Impact of integrated marketing on the printing industry. Retrieved May 12, 2013 from http://www.capv. com/public/home.html

De Pelsmacker, P., Geuens, M. \& Anckaert, P. (2002). Media context and advertising effectiveness: The role of context appreciation and context/ad similarity. Journal of Advertising, 49-61.

Elliott, G. R. \& Cameron, R. C. (1994). Consumer perception of product quality and the country-of-origin effect. Journal of International Marketing, 2(2), 49-62.

EuropeMedia. (2002). 60\% of consumers would not pay for online services.

Evans, P. B. \& Wurster, T. S. (1997). Strategy and the new economics of information. Harvard Business Review, 75(5), 70-82.

Kotler, P. \& Gertner, D. (2002). Country as brand, product, and beyond: A place marketing and brand management perspective. The Journal of Brand Management, 9(4), 249-261. 
Lavidge, R. J. \& Steiner, G. A. (1961). A model for predictive measurements of advertising effectiveness. The Journal of Marketing, 59-62.

Liefeld, J. P. (1993). Experiments on country-of-origin effects: Review and meta-analysis of effect size. In Papadopoulos, N. \& Heslop, L. (eds.). Product-country images: Impact and role in international marketing (pp. 117-156). NY: International Business Press.

Kakkar, P. \& Lutz, R. (1981). Situational influence on consumer behavior: A review. In: Kassarjian, H. \& Robertson, T. (eds.). Perspectives in Consumer Behavior. Foresman.

Mings, S. M. \& White, P. B. (2000). Profiting from online news: The search for viable business models. In Kahin, B. \& Varian, H. R. (eds.), Internet publishing and beyond: The economics of digital information and intellectual property (pp.62-96). Cambridge: MIT Press.

NewMediaAge (2009, 14 de mayo). Further publishers investigate moving to paid-for content.

Newspaper Association of America (2013). Advertising expenditures. Retrieved March 22, 2013 from: http://www.naa.org/Trends-andNumbers/Advertising-Expenditures/Annual-All-Categories.aspx

Park, W. (1976). The effect of individual and situation-related factors on consumer selection of judgmental models. Journal of Marketing Research, 13, pp. 144-151.

Peter, P. \& Tarpey, L. (1975). A comparative analysis of three consumer decision strategies. Journal of Consumer Research, 2 (1), 29-37.

Peterson, R. \& Jolibert, A. (1995). A meta-analysis of country-of-origin effects. Journal of International Business Studies, 26(4), 883-900. 
Pew Research Center for the People \& the Press (2008). Internet overtakes newspapers as news outlet. Retrieved March 22, 2013 from: http:// people-press.org/reports/pdf/479.pdf

Picard, R. G. (2000). Changing business models of online content services: Their implications for multimedia and other content producers. International Journal on Media Management, 2(2), 60-68.

PriceWaterhouseCoopers (2009). Moving into multiple business models. Retrieved April 12, 2013 from: http://www.pwc.com/extweb/pwcpublications.nsf/docid/80B8E15DAE7DEEFD8525759F0020C4EB

Reierson, C. (1967). Attitude changes toward foreign products. Journal of Marketing Research, 4(4), 385-387.

Richter, F. (2012). Google rakes in more ad dollars than U.S. print media. Retrieved November 12, 2013, from http:/ /www.statista.com/topics/1001/google/chart/709/google-s-ad-revenue-since-2004/

Russel, J. T. \& Lane, W. R. (2001). Publicidad. México: Pearson.

Russell, T., Lane, W. R., \& Kleppner, O. (1993). Kleppner's advertising procedure. Prentice Hall.

Schultz, D. E., Tannenbaum, S. I. \& Lauterborn, R. F. (1992). Integrated Marketing Communications. Taylor \& Francis.

Schultz, D. E. \& Schultz, H. F. (2004). IMC, the next generation: Five steps for delivering value and measuring financial returns. McGraw-Hill.

Solomon, M. (2007). Consumer behavior. Buying, having and being. New Jersey: Pearson Education.

VV.AA. (2013). Estudio de la inversión publicitaria en España. Retrieved April 12, 2013 from http://www.infoadex.es/estudios.html 